\title{
THIN LAYER DRYING OF WATERMELON SEEDS (Colocynthis Citullus)
}

\author{
M. A. Mosallam*, A. K. Zaalouk* and R. A. Werby**
}

\section{ABSTRACT}

This research aims to the determination of the optimum temperature and air velocity required for drying a thin layer of watermelon seeds (Colocynthis Citullus). For sitting up of these seeds for snapping. Watermelon seeds were dried under four temperatures which are: 40, 50, 60 and $70{ }^{\circ} \mathrm{C}$. Under each drying temperature, four air velocities were tested. These velocities are: 0.5, 1, 1.5 and $2 \mathrm{~m} / \mathrm{s}$. drying time was $7 \mathrm{~h}$ for all treatments. The drying rate constant " $\mathrm{k}$ " $\left(\mathrm{min}^{-1}\right)$ was calculated for each of the previously mentioned treatments. The study concluded to that The greatest value of " $k$ " is at $50{ }^{\circ} \mathrm{C}$ drying temperature and $2 \mathrm{~m} / \mathrm{s}$ drying velocity and calculated to be $0.0123 \mathrm{~min}^{-1}$.

\section{INTRODUCTION}

$\mathrm{S}$ eed watermelon is one of the vegetables whose cultivation is being spread at the North of delta and at the new reclaimed areas for its importance in producing oil or (Halawa Tehneia_الحلاوة الطحينية) or as a crop for exporting.

Watermelon seed ( Colocynthis Citrullus) is an oil seed, which contains approximately $50 \%$ by weight oil, $28.4 \%$ proteins ( $60 \%$ of defatted flour ), $2 . .7 \%$ fiber, $3.6 \%$ ash and $8.2 \%$ carbohydrate (Oyenuga and Fetuga, 1975).The seed is also a good source of essential amino acids.

In Egypt, the total watermelon cultivated area is about 174407 feddan, which produces 101013 tons approximately with an average yield of 579 $\mathrm{kg} /$ feddan ( Ministry of Agriculture and land Reclamation 2009). Watermelon seeds are stored at moisture content of $8-29 \%$ (Burubai et al 2008). When the seeds are taken out of the storage for the purpose of entertainment (major part of the produced watermelon seeds in Egypt is used for human snapping), watermelon seeds are soaked for $24 \mathrm{~h}$ in water, then drained. Then they are toasted.

\footnotetext{
* Assoc. Prof., Agr. Eng. Dept., Fac. of Agr., Al-Azhar Univ., Cairo. ** Lect., Agr. Eng. Dept., Fac. of Agr., Al-Azhar Univ., Cairo.
} 
So moisture content of watermelon seeds used for entertainment is relatively high compared with its storage moisture content. This research aimed to drying watermelon seeds to a moisture content of about $50 \%$ (wt. b).

\section{REVIEW OF LITERATURE}

The basic objective of drying agricultural products is the removal of the moisture of the solid part of the product up to a certain level at which microbial spoilage, deterioration and chemical reactions are greatly minimized ( Krokida and Marinos - Kouris 2003). Sahin and Dincer ( 2005) reported that: when subjecting to thermal drying of the wet solid part of an agricultural product, two processes occur simultaneously: transfer of energy (most as heat) from the surrounding environment to evaporate the surface moisture of the product and transfer of the internal moisture of the product to its surface and moisture subsequent evaporation due to the first process. Doymaz ( 2005) reported that the traditional open air- sun drying technique commonly employed in the tropics for drying grains, fruits, and vegetables has some disadvantages which include, the slow speed of the process, contamination due to exposure to the environmental conditions and the hard labor requirement. Karathanos and Bellesiotis (1997) stated that drying watermelon seeds by the direct exposure to solar radiation results in undesirable color changes, significantly lowering quality of the dried products significantly. Therefore, the use of solar and hot air dryers, which are far more rapid and which provide uniformity and hygiene for industrial food drying processes become inevitable. Li and Morey ( 1984 ) developed an equation to determine thin- layer drying rates for yellow dent corn as affected by drying air temperature, air flow rate, initial moisture content and relative humidity. They found that drying air temperature had the greatest effect on drying rates. Initial moisture content also influenced drying rates. Air flow rate and relative humidity had smaller effects. Brooker et al. ( 1978) reported that several parameters influence the time required to reduce the dried product to the desired moisture content for a particular grain. These parameters include air temperature, air relative humidity, airflow rate, original moisture content, and final moisture content. These parameters are considered in the design of the drying equipment and are manipulated in the process of drying the grain 
within the time limit selected. Also, they mentioned that better quality of the dried product is obtained when heated air is reused for the drying process. Hall (1980) showed that the drying rate constant $(\mathrm{K}) \mathrm{min}^{-1}$ is affected by temperature and relative humidity of drying air and moisture content (d.b) of the dried product. The given table illustrates the effect of some values of these factors on $(\mathrm{K})$.

\begin{tabular}{|c|c|c|c|}
\hline $\begin{array}{c}\text { Temperature } \\
\left({ }^{\circ} \mathrm{C}\right)\end{array}$ & $\begin{array}{c}\text { Relative } \\
\text { Humidity } \\
(\%)\end{array}$ & $\begin{array}{c}\mathrm{K} \\
\left(\mathrm{min}^{-1}\right)\end{array}$ & $\begin{array}{c}\text { Range of } \% \\
\text { moisture (d. b) }\end{array}$ \\
\hline 4.4 & 14.0 & 0.0750 & 29.96 to 24.79 \\
\hline 15.6 & 76.0 & 0.0583 & 27.20 to 25.20 \\
\hline 60.0 & 11.2 & 0.3380 & 47.00 to 19.00 \\
\hline 60.0 & 55.0 & 0.2710 & 43.60 to 13.00 \\
\hline
\end{tabular}

\section{MATERIAL AND METHODS}

Apparatus used:

An experimental dryer was constructed at the workshop of the Dept. of Agr. Eng., Fac. of Agr., Al Azhar Univ. The dryer was fitted with a temperature control system. The dryer consists of three main sections, a forced air section, an air heating section and a drying section.

1 - The forced air section consists of an axial flow air fan controlled by an electric regulator with variable speeds of $0.5,1,1.5$ and $2 \mathrm{~m} / \mathrm{s}$. 2 - The air heating section consists of an electric heater, an electric switch and an air drying chamber. An electric heater of $0.2 \mathrm{kw}$ power was used to heat air flowing to the air chamber. The electric switch is of variable resistance to control the drying temperature. The switch was attached to the heater to change its electric current supply to provide suitable air heating temperature for the drying process. The air drying chamber is rectangular in shape and is made of sheet iron.

3 - The drying section consists of a rectangular chamber made from galvanized sheet iron. Dimensions of the chamber are: $40 \mathrm{~cm}$ long, $20 \mathrm{~cm}$ wide and $20 \mathrm{~cm}$ height. The chamber was covered with a foam layer as an insulating material to reduce heat losses from the drying chamber. Inside the chamber, a drying tray of $15 \times 40 \mathrm{~cm}^{2}$ dimensions was placed. Two thermometer sets each consisting of a dry and a wet bulb thermometers were attached to the inlet and outlet sides of the drying section. 


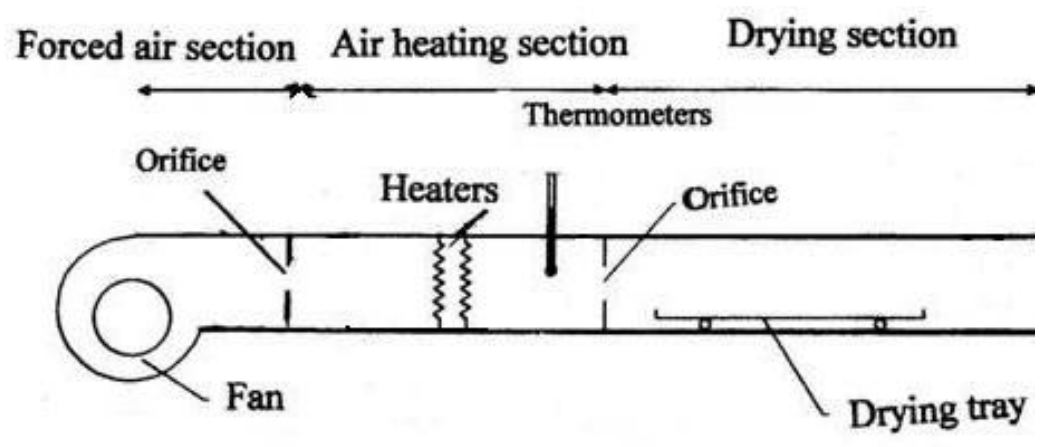

Fig. (1): Schematic diagram of experimental dryer.

Instruments used:

1 - A turbo meter (source: U.S.A., type: electronic model No: 5951 - 75, sensitivity: $0.1 \mathrm{~m} / \mathrm{s}$ ) was used to measure the air velocity during drying process.

2 - A stop watch was used for measuring the drying time

3 - A digital balance was used for measuring the weight of the sample of watermelon seed during drying. Range of the balance is up to $5 \mathrm{~kg}$ with a sensitivity of $0.1 \mathrm{~g}$.

Variables investigated:

Drying experiments were carried out at drying air temperatures of 40,50 , 60 and $70{ }^{\circ} \mathrm{C}$. Under each temperature, four air velocities were investigated. These velocities were: $0.5,1,1.5$ and $2 \mathrm{~m} / \mathrm{s}$. This means that 16 treatments were carried out.

Drying time and measuring moisture content:

For each of the previously mentioned 16 treatments, drying time was 420 $\min (7 \mathrm{~h})$. For the first $60 \mathrm{~min}(1 \mathrm{~h})$ of drying, moisture content was determined each $10 \mathrm{~min}$. For the subsequent $240 \mathrm{~min}(4 \mathrm{~h})$, moisture content was determined each $30 \mathrm{~min}$. For the rest of the drying period, $120 \mathrm{~min}(2 \mathrm{~h})$, moisture content was determined each $60 \mathrm{~min}$

Calculations carried out:

1 - Moisture content (dry basis), ( M.C. d.b ):

For the determination of the moisture content of the tested watermelon seeds, random samples of the seeds were dried for $24 \mathrm{~h}$ under $105^{0} \mathrm{C}$.

The moisture content was calculated by the following relation, Silayo (1995) and Kajuna et al., ( 2001): 


$$
\text { M.C }=\frac{\text { Mwet }- \text { Mdry }}{\text { Mdry }} \text { x } 100
$$

where;

M.C : moisture content, dry basis ( \% ).

Mwet : mass of wet samples, $(\mathrm{g})$.

Mdry : mass of dry samples, ( $\mathrm{g}$ ).

2 - Moieture ratio (MR) and drying rate constant, (k):

The Drying rate constant $(\mathrm{k})$ is determined according to the relation, Togrul, I. T. and Pahlivan. D. (2002) :

$$
\mathrm{MR}=\frac{\mathrm{M}_{\mathrm{t}}-\mathrm{Me}}{\mathrm{Mi}-\mathrm{Me}}=\exp ^{-\mathrm{kt}}
$$

Where:

MR : Moisture ratio, \% (d.b).

Mi : Initial moisture content, \% (d.b).

Mt : Moisture content at any time during drying, \% (d.b).

Me: Equilibrium moisture content, \% (d.b).

$\mathrm{k}$ : drying rate constant $\left(\min ^{-1}\right)$.

$\mathrm{t}$ : drying time, min.

3 - Determination of the drying rate constant, (k):

By using equation (2), "k" was expressed in a linear form as follows:

$\ln \mathrm{MR}=-\mathrm{kt}$

So, plotting ln MR vs." t" results in a slopping down straight line whose slope is $\mathrm{k}$.

\section{RESULTS AND DISCUSSION}

The initial moisture content of the watermelon seeds was $67 \%$ (d. b).

\section{1 - Effect of drying time on moisture content and moisture ratio:}

Figs. 2 through 5 show the relation between drying time (min) and moisture content $(\%$ d. b) while Figs. 6 through 9 show the relation between drying time ( $\mathrm{min}$ ) and moisture ratio of watermelon seeds under the four tested drying temperatures $\left(40,50,60\right.$ and $\left.70^{\circ} \mathrm{C}\right)$ and the four 
tested air velocities $(0.5,1,1.5$ and $2 \mathrm{~m} / \mathrm{s})$. From these curves it can be concluded that: for all treatments, the drying rate is high at the beginning of the drying process, then this rate decreases and approaches zero at the end of the drying process. Also, for all treatments, drying rate is higher with the drying temperatures as evident by the steeper slopes of curves at higher temperatures. Air velocities tested affected drying rates at the beginning of drying time, and as drying time increases, the air velocities tested seem to have no influence on the drying rate. The obtained results show that the moisture content of dried seeds decreases with increasing drying time for different drying temperatures and air velocities. The least the moisture content (10\% d.b) was obtained at $70{ }^{\circ} \mathrm{C}$ drying temperature and $1.5 \mathrm{~m} / \mathrm{s}$ air velocity. highest of moisture content $(120 \% \mathrm{~d}$. b) was obtained at $40{ }^{\circ} \mathrm{C}$ drying temperature and $0.5 \mathrm{~m} / \mathrm{s}$ air velocity.

The drying curves show the variation of moisture ratio with drying time at different temperatures and air velocities. lowest of the moisture ratio $\left(0.009 \%\right.$ d. b) was obtained at $50{ }^{\circ} \mathrm{C}$ drying temperature and $1.5 \mathrm{~m} / \mathrm{s}$ air velocity. The maximum value of moisture ratio $(0.88 \%$ d. b) was obtained at $40{ }^{\circ} \mathrm{C}$ drying temperature and $0.5 \mathrm{~m} / \mathrm{s}$ air velocity.

\section{2 - The Drying rate constant $(k)$ :}

Table (1) shows the values of the constant $\mathrm{k}$ under different drying temperatures and air velocities.

Table (1): Drying rate constants.

\begin{tabular}{|l|c|c|c|c|c|c|c|c|}
\hline \multirow{2}{*}{$\begin{array}{l}\mathrm{T} \\
\mathrm{V} \\
(\mathrm{m} / \mathrm{s})\end{array}$} & \multicolumn{2}{|c|}{40} & \multicolumn{2}{c|}{50} & \multicolumn{2}{c|}{60} & \multicolumn{2}{c|}{70} \\
\cline { 2 - 9 } & $\mathrm{K}\left(\mathrm{min}^{-1}\right)$ & $\mathrm{R}^{2}$ & $\mathrm{~K}$ & $\mathrm{R}^{2}$ & $\mathrm{~K}$ & $\mathrm{R}^{2}$ & $\mathrm{~K}$ & $\mathrm{R}^{2}$ \\
\hline 0.5 & & & & & & & & \\
\hline 1 & $\mathbf{0 . 0 0 8 1}$ & $\mathbf{0 . 9 7 1}$ & $\mathbf{0 . 0 0 9 9}$ & $\mathbf{0 . 9 7 9}$ & $\mathbf{0 . 0 1 0 2}$ & $\mathbf{0 . 9 8 3}$ & $\mathbf{0 . 0 1 0 2}$ & $\mathbf{0 . 9 8 8}$ \\
\hline 1.5 & $\mathbf{0 . 0 1 0 2}$ & $\mathbf{0 . 9 8 7}$ & $\mathbf{0 . 0 1 2 4}$ & $\mathbf{0 . 9 9 0}$ & $\mathbf{0 . 0 1 1 7}$ & $\mathbf{0 . 9 9 2}$ & $\mathbf{0 . 0 1 1 4}$ & $\mathbf{0 . 9 9 5}$ \\
\hline 2 & $\mathbf{0 . 0 1 3 0}$ & $\mathbf{0 . 9 9 0}$ & $\mathbf{0 . 0 1 4 4}$ & $\mathbf{0 . 9 9 2}$ & $\mathbf{0 . 0 1 3 0}$ & $\mathbf{0 . 9 9 7}$ & $\mathbf{0 . 0 1 2 9}$ & $\mathbf{0 . 9 9 7}$ \\
\hline
\end{tabular}

Table (1) shows that the highest " $\mathrm{k} "$ is $0.0144 \mathrm{~m}^{-1}$ at drying temperature $50{ }^{0} \mathrm{C}$ and air velocity $1.5 \mathrm{~m} / \mathrm{s}$. The lowest "k" is $0.0081 \mathrm{~min}^{-1}$ at temperature $40{ }^{\circ} \mathrm{C}$ and velocity $0.5 \mathrm{~m} / \mathrm{s}$. 

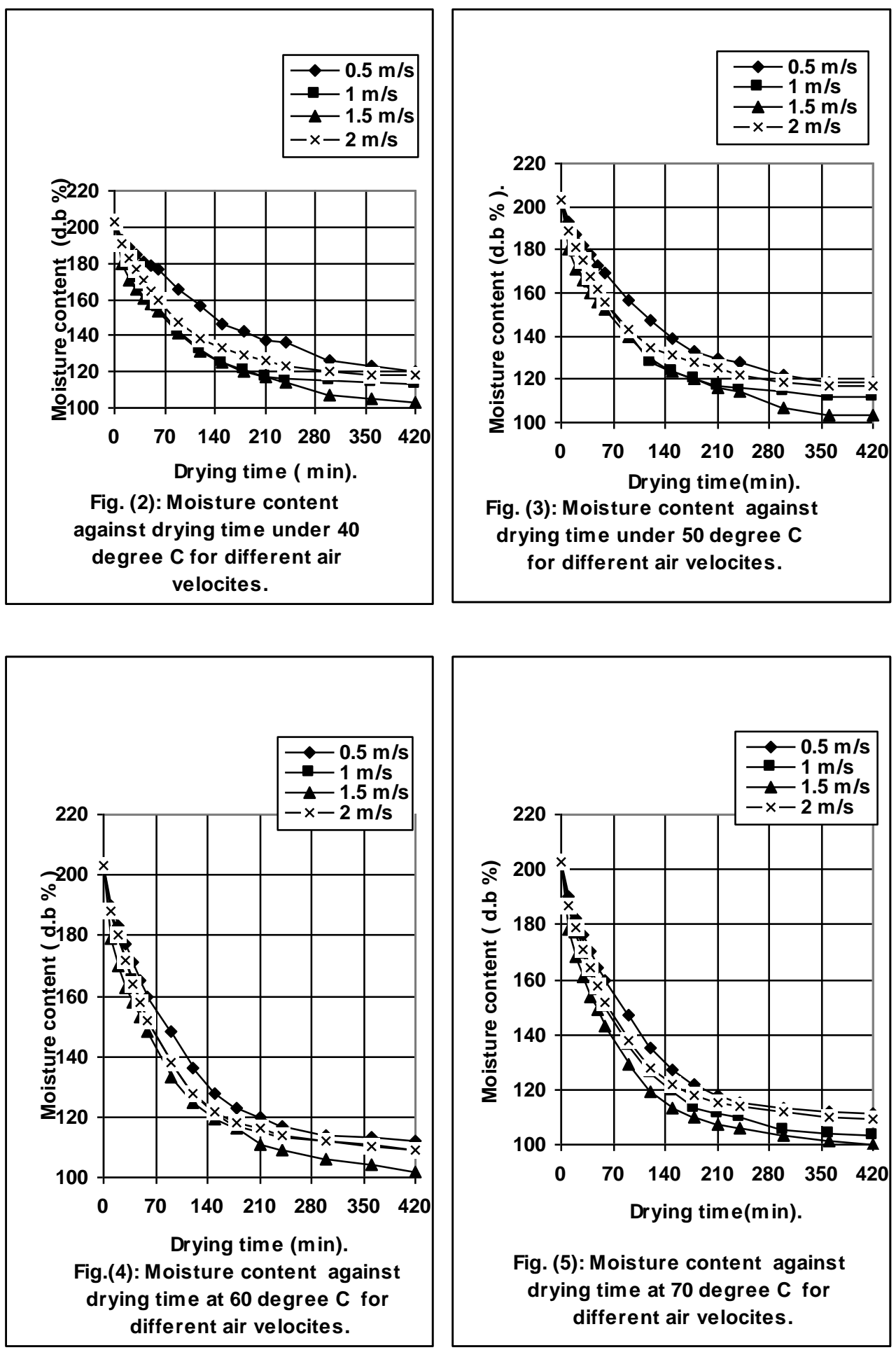

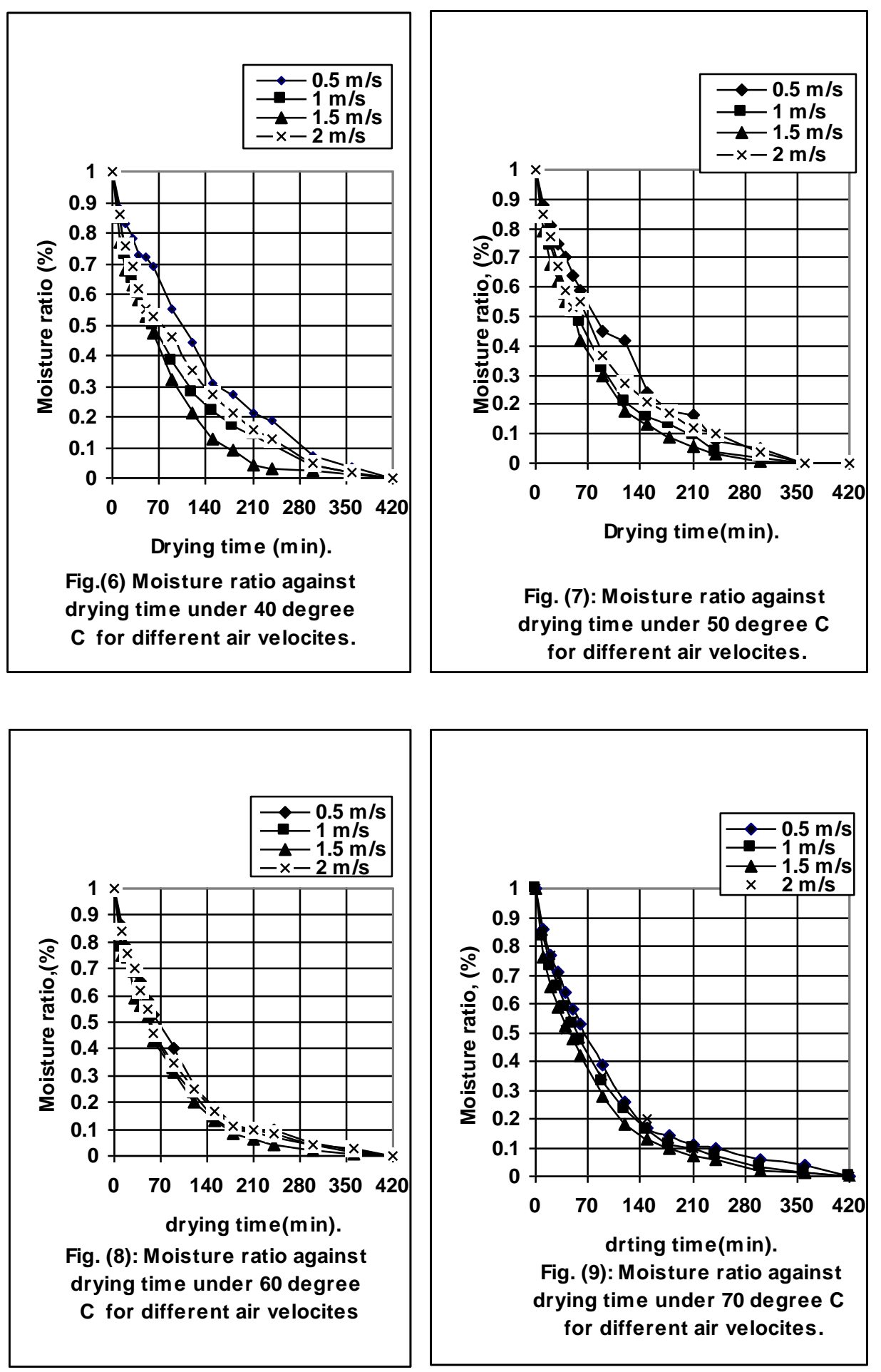
Determination of the optimum conditions required for drying watermelon seeds:

Fig.(10), shows the relation between drying velocity "v": 0.5, 1.0, 1.5 and $2 \mathrm{~m} / \mathrm{s}$. and the drying constant $\left(\mathrm{k}, \mathrm{min}^{-1}\right)$ at the drying temperatures "T": 40, 50,60 and $70{ }^{\circ} \mathrm{C}$.

The values of "k" at each drying temperature were fitted to a linear function.

from the figure it can be concluded that:

1- under each drying temperature, " $k$ " increases as drying velocity increases.

2- The greatest value of " $\mathrm{k}$ " is obtained at $50{ }^{\circ} \mathrm{C}$ drying temperature.

3- The to curves which represents the values of "k" at 60 and $70{ }^{\circ} \mathrm{C}$ are identical.

4- The least value of " $\mathrm{k}$ " is obtain is $40{ }^{\circ} \mathrm{C}$.

5- From the previous discussion, the greatest value of " $\mathrm{k}$ " is obtained at $50{ }^{\circ} \mathrm{C}$ drying temperature and $2 \mathrm{~m} / \mathrm{s}$ drying velocity.

6- According to figure 10, the greatest value of " $k$ " were calculated and found to be $0.0123 \mathrm{~min}^{-1}$

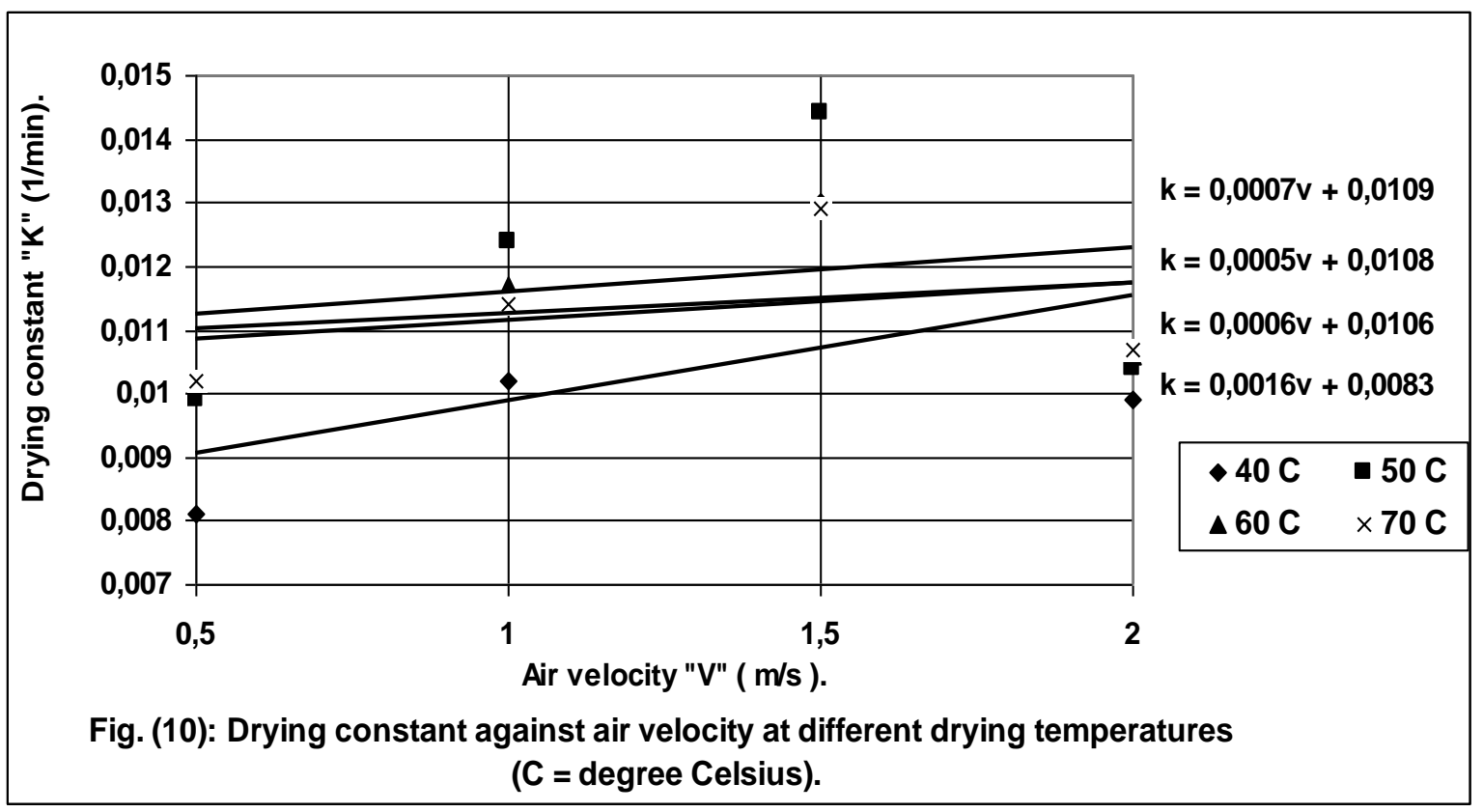




\section{SUMMARY}

This research aims at the determination of the optimum temperature and air velocity required for drying a thin layer of watermelon seeds (Colocynthis Citullus) for the purpose of consumption by snapping. To achieve this goal, an experimental dryer was designed and constructed. Watermelon seeds (of moisture content of $67 \%$ wt. b) were dried, to a moisture content of about $50 \%$ (wt. b) under four temperatures which are: 40, 50, 60 and $70{ }^{\circ} \mathrm{C}$. Under each drying temperature, four air velocities were tested: $0.5,1,1.5$ and $2 \mathrm{~m} / \mathrm{s}$. Drying time was $7 \mathrm{~h}$ for all treatments. The drying rate constant " $\mathrm{k}$ " $\left(\mathrm{min}^{-1}\right)$ was calculated for each of the previously mentioned treatments.

The study concluded to that:

1- The greatest value of " $\mathrm{k}$ " is obtained at $50{ }^{\circ} \mathrm{C}$ drying temperature and $2 \mathrm{~m} / \mathrm{s}$ drying velocity and calculated to be $0.0123 \mathrm{~min}^{-1}$.

2- The values of "k" at 60 and $70{ }^{\circ} \mathrm{C}$ drying temperature are identical.

3- The least value of " $\mathrm{k}$ " is obtain is $40{ }^{\circ} \mathrm{C}$ drying temperature.

\section{REFERANCES}

Brooker, D . B., F . W. Baker Arkema and C . W .Hall ( 1978 ). Drying cereal grian $2^{\text {nd }}$ Edition AVI publishing Co., Westport, Conn., INC., USA

Brubai W., A. J. Akor, A. H. Igoni and Y. T. Puyate (2008). Fracture resistance of African nutmeg (Monodora myristica) to compressive loading. Am - Eurasian J. of Sci. Res. 3(1): 15-18.

Doymaz, I. ( 2005). Drying behaviour of green beans Journal of Food Engineering 69: 161- 165.

Hall, W. H. (1980). Drying and storage of agricultural crops. AVI Pub. Co.: 129 .

Karathanos, V . T and Belessiotis, V . G . ( 1997). Sun and artificial air drying kinetics of some agricultural products, J. Food Engineering $31: 35-46$.

Krokida, M. K. and Marinos - kouris, D. ( 2003). Dehydration kinetics of dehydrated products - Journal of Food Engineering $57: 1-7$. 
Li, H. and R. V . Morey ( 1984 ). Thin - layer drying of yellow dent corn. Trans. ASAE: $581-585$.

Ministry of Agriculture and Land Rec. Statistical year Book

Oyenuya, V . A .and Fetuga, B . A . ( 1975 ) Some aspects of biochemistry and nutritional value of water melon .Journal of the science of food and Agriculture, 26 ( 6): 843 - 854.

Silayo, V. C. K. (1995). Sun drying of Grains. Univ. of Newcastle Upon-tyne, Uk. Ph. D. Thesis.

Togrul, I. T. and Pahlivan. D. (2002). Mathematical modeling of solar drying of apricots in thin layers. J. Food Eng. , 55, $209: 216$

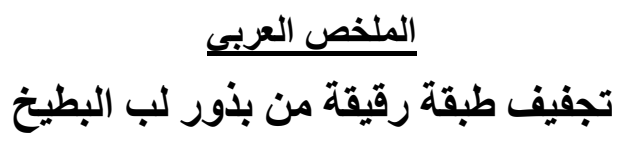

(Colocynthis Citullus)

محمود أحمد مسلم*، أشرف كامل زعلوك* و رأفت على وربى*

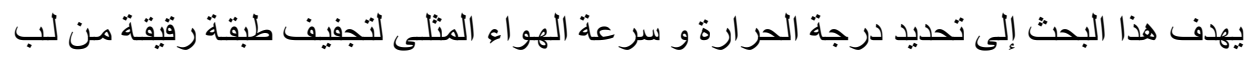

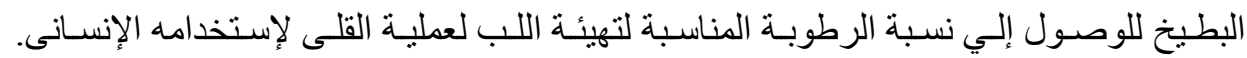

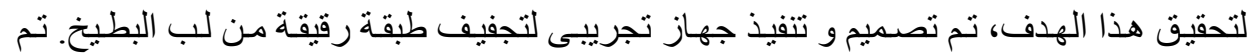

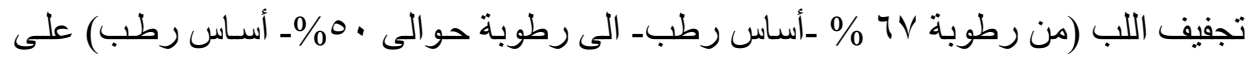

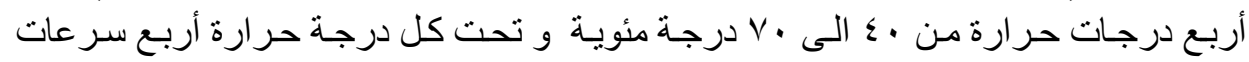

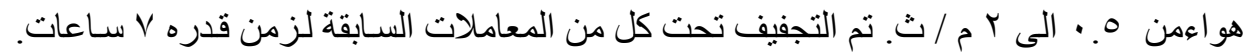
تم حساب ثنابت معدل التجفيف "k " " ( الدقيقة) تحت كل من المعاملات السابقة. كانت نتائج البحث كالتالى:

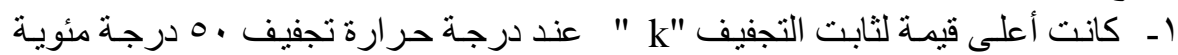

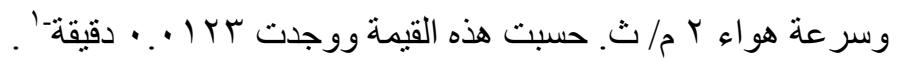

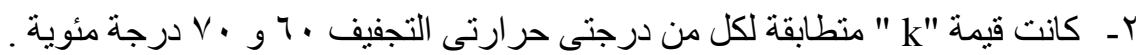

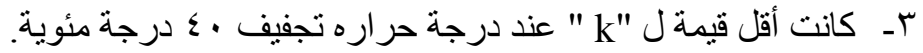

* أستاذ مساعد ـ قسم الهندسة الزراعية _ كلية الزراعة ـ جامعة الأزهر - القاهرة. * * مدرس ـ قسم الهندسة الزراعية ـ كلية الزراعة - جامعة الأزهر - القاهرة. 